\title{
BIO-GEOCHEMICAL SIMULATION FOR SOLUTE TRANSPORT IN PIYUNGAN LANDFILL, YOGYAKARTA SPECIAL PROVINCE, INDONESIA
}

\author{
Keophousone Phonhalath ${ }^{* 1}$, Dwikorita Karnawati ${ }^{1}$, Heru Hendrayana ${ }^{1}$, Doni Prakasa \\ Eka Putra ${ }^{1}$, and Kenji Jinno ${ }^{2}$ \\ ${ }^{1}$ Department of Geological Engineering, Gadjah Mada University, Yogyakarta, Indonesia \\ ${ }^{2}$ Urban and Environmental Engineering Department, Faculty of Engineering, Kyushu University, Japan
}

\begin{abstract}
Piyungan Landfill is the largest in Bantul Regency. According to water quality sampling taken from a leachate pond, there are significant contaminant issues resulting from landfill leachate. The objectives of this research were achieved by applying a twodimensional bacteria mediated reduction numerical model was applied. Method of characteristic was applied to solve the advection part of the solute transport equation. Three bacteria $\left(X_{1}, X_{2}\right.$, and $\left.X_{3}\right)$ groups were defined in the redox model. In the conceptual model, bacterial $X_{1}$ utilizes oxygen under aerobic conditions and nitrate, $\mathrm{NO}_{3}^{-}$under aerobic conditions as electron acceptors. Consequently, under aerobic conditions bacteria $X_{2}$, and $X_{3} u t i-$ lize $\mathrm{MnO}_{2}$, and $\mathrm{Fe}(\mathrm{OH})_{3}$ respectively as electron acceptors. In the redox model organic carbon which was defined as $\mathrm{CH}_{2} \mathrm{O}$ was considered as the electron donor for all bacteria mediated reduction reactions. The results of research are to improve the understanding of biogeochemical processes in aquifer.
\end{abstract}

Keywords: landfill leachate, hydrogeological factors, numerical model, redox modeling.

${ }^{*}$ Corresponding author: KEOPHOUSONE P., Department of Geological Engineering, Faculty of Engineering, Gadjah Mada University, Jl. Grafika 2 Yogyakarta, 55281, Indonesia. E-mail: keophousone@yahoo.com

\section{Introduction}

Piyungan landfill is a dumping site of waste disposal from human activities' products, which has operated since 1995 and is the biggest landfill in Bantul Regency. Day by day the wastes are increasing in Yogyakarta and dumped in Piyungan landfill that can produce leachate (wastewater from leachate), which gives value of contaminant concentration. Based on Putra et al. (2001), the research for two-dimensional horizontal solute transport had been done; the plume was extended along the flow which moves from southern to northern part (Putra, 2001).

Furthermore, the existing of sanitary landfill still can bring a negative impact to the surrounding environment. The problems of groundwater contamination from leachate leakage always occur on the aquifer on the landfill area. Issue of groundwater contamination such as heavy metal and dissolved organic carbon, caused by leachate leakage in Piyungan Landfill has been reported by the local communities of Banyakan village (Putra et al., 2001). Banyakan village is located more or less $700 \mathrm{~m}$ northern of Piyungan landfill (Figure 1).

Beside that there are still many researches of groundwater in Yogyakarta which are being performed. Some graduation papers of undergraduate and postgraduate students of Gadjah 


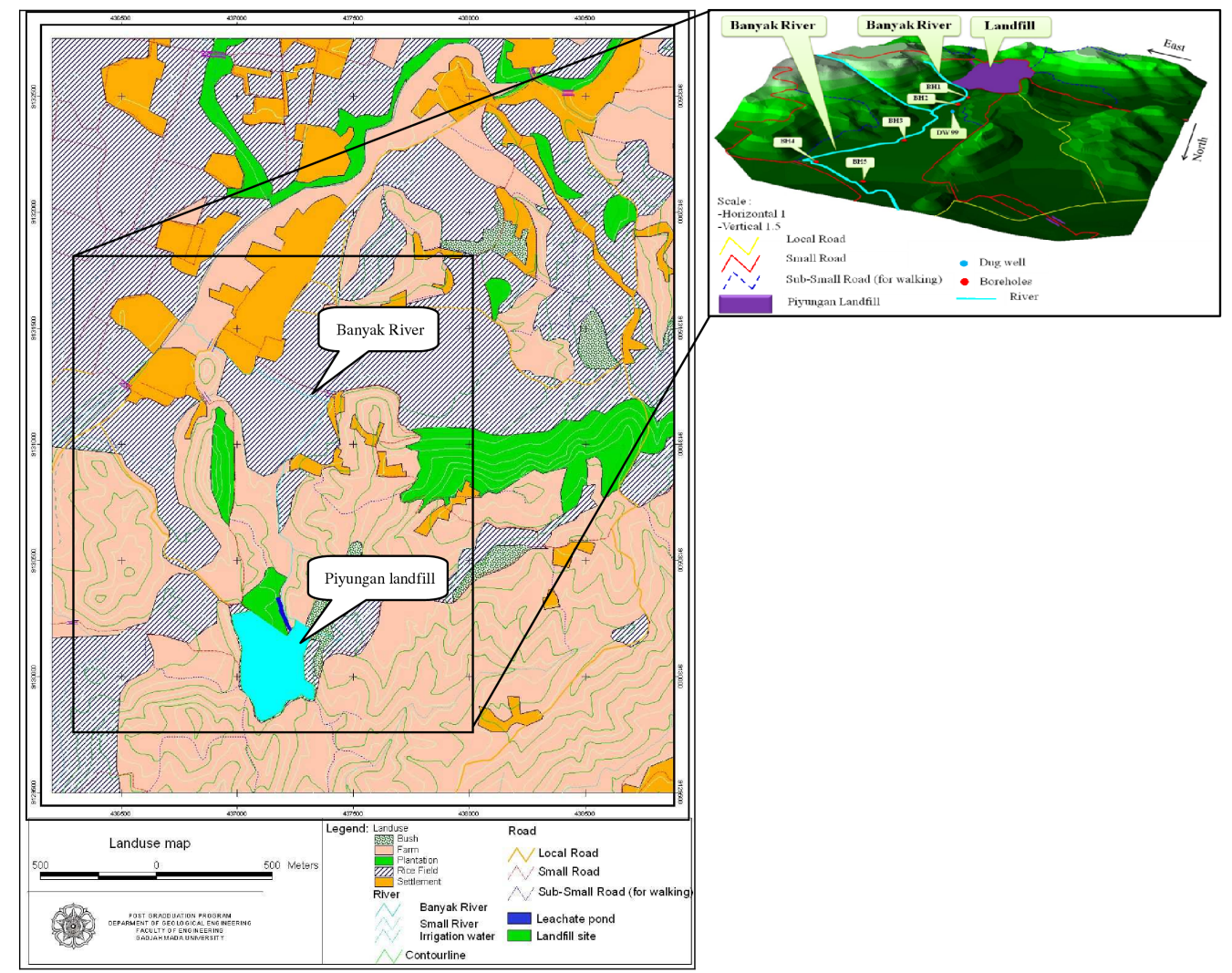

Figure 1: Location map and tree-dimensional view of the study area (North-South)

Mada University are contributed to groundwater problem in Bantul regency. Although many researches of groundwater had been done in this landfill, the study about contaminant transport from Piyungan landfill must be continued to give more understanding about redox reaction in groundwater systems.

Therefore, in order to give more understanding of contaminant transport from landfill, the modeling of redox from landfill will be focused on this research works must be simulated.

\section{Site condition}

This study area occupies the morphology of the river plains of the railroad. It is the result of fluvial deposition of Opak river. This unit spreads widely about $10.58 \%$ of the total mapped area. As well as alluvial deposits, outcrops of this unit found along river banks of Opak (Putra, 2001). Description and the characteristics of Opak fluvial deposit is as follows: spreading along the flow of Opak river, brown- gray, clayey sand-sized further down the coarse grain size and gravel, sorting is quite good, layered with changes not clear, and below are the tuffaceous sandstones and agglomerates. The thickness on the river bank of Opak river reachs approximately 12-15 meters (see Figure 2).

\section{Theoretical Background}

Based on the research of Perera et al. (2009), the model explains the utilization of $\mathrm{O}_{2}, \mathrm{NO}_{3}^{-}$, $\mathrm{MnO}_{2}, \mathrm{Fe}(\mathrm{OH})_{3}$ and $\mathrm{SO}_{4}^{2-}$ as electron acceptors for oxidation of organic carbon in the aquifer under aerobic and anaerobic conditions. The conceptual model consists of three different phases named as bio phase, mobile phase and matrix phase. Model parameters are adopted from literature on bacteria mediated multi-component modelling and bioremediation processes. Monod kinetic equation is used to formulate the bacterial growth (Perera et al., 2009). The model explains the behaviours of aerobic and anaerobic bacteria under the avail- 


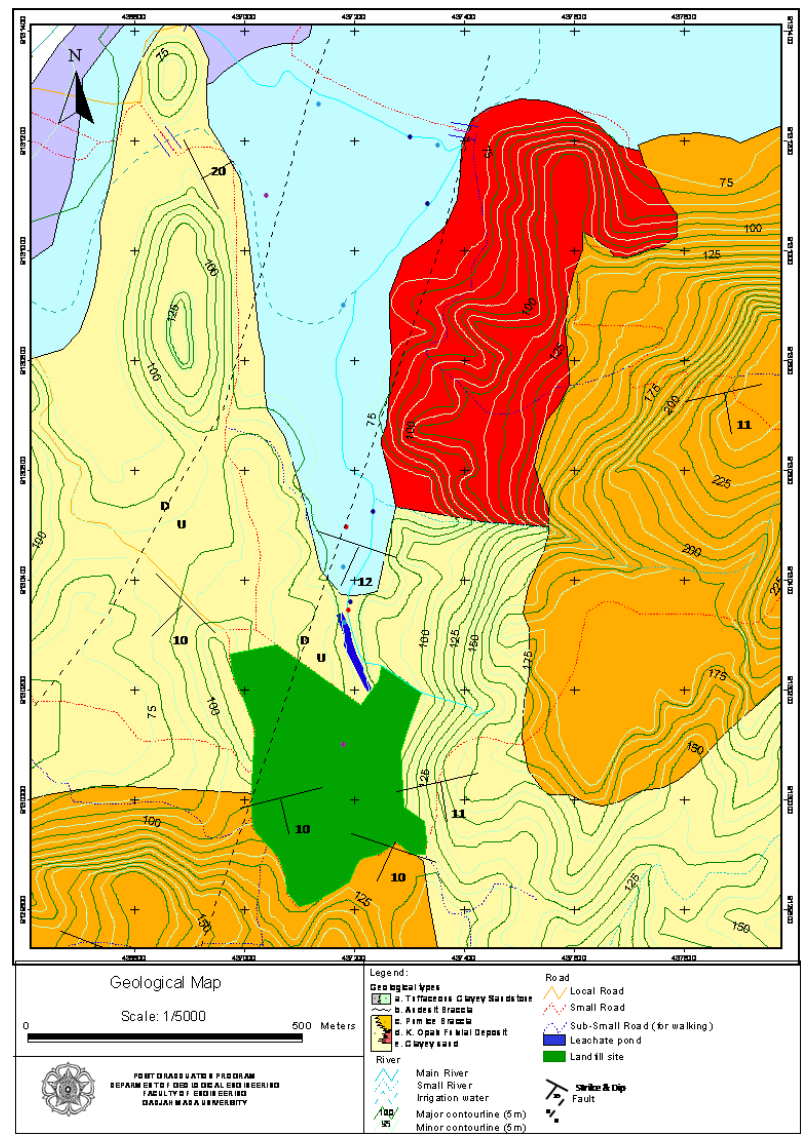

Figure 2: Geological map of study area (redrawn and modified from Putra, 2001)

ability of organic carbon. The redox simulation of this research focuses on the possibility of the simulation of the formation of reduced environments in groundwater aquifers which purpose to know and understand the redox reaction in groundwater environment (Figure 3).

Bacteria group $X_{1}$ uses oxygen under aerobic conditions and $\mathrm{NO}_{3}^{-}$under anaerobic conditions as electron acceptor. Anaerobic bacterial groups $X_{2}, X_{3}$ and $X_{4}$ use $\mathrm{MnO}_{2}, \mathrm{Fe}(\mathrm{OH})_{3}$ and $\mathrm{SO}_{4}^{2-}$ as electron acceptors respectively (Perera et al., 2009). Organic carbon which behaves as the electron donor is considered as the most important factor for the bacteria mediated reduction processes (Figure 3). On the Figure 3 shows the chemical species considered in the redox model and species exchange between different phases. The redox model describes the interactions between $\mathrm{O}_{2}, \mathrm{NO}_{3}^{-}, \mathrm{MnO}_{2}, \mathrm{Fe}(\mathrm{OH})_{3}$, $\mathrm{SO}_{4}^{2-}$, organic carbon concentrations, bacterial growth, precipitation of $\mathrm{Fe}(\mathrm{OH})_{3}$ in the mixing zone of the water region source.

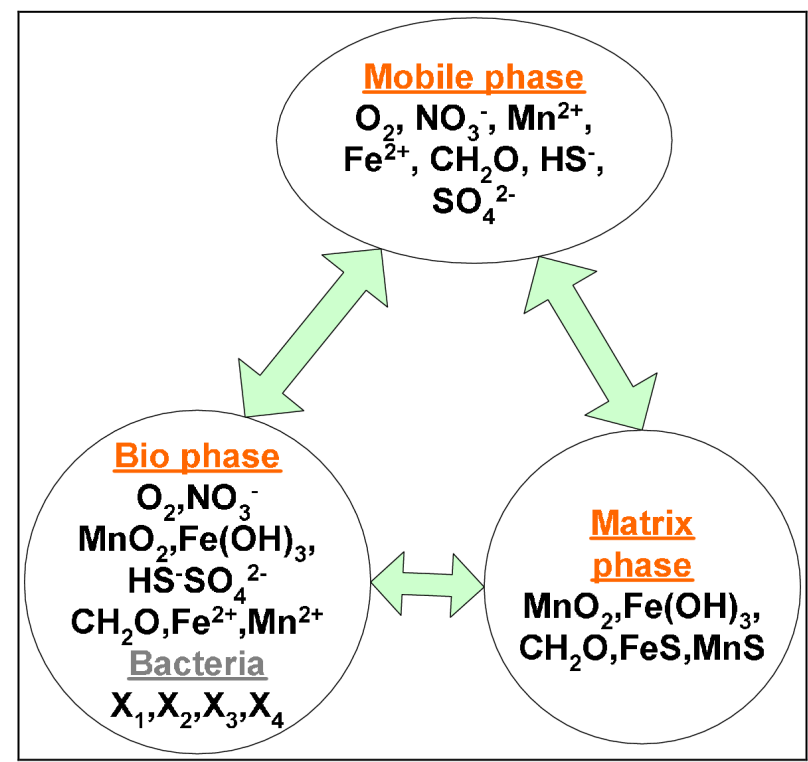

Figure 3: Conceptualization of redox model (Perera et al., 2009)

Exchange processes considered between the different model phases can be summarized as; (a) the mobile phase and the bio phase; (b) the mobile phase and the matrix phase; and (c) the bio phase and the matrix phase. The redox model describes the biological degradation of organic carbon by different bacterial groups and the precipitation of $\mathrm{Fe}(\mathrm{OH})_{3}$ and FeS (Perera et al., 2009). Microbial mediated redox sequences of reactions as shown in Figure 4, (aerobic oxidation, $\mathrm{NO}_{3}^{-}$reduction, $\mathrm{MnO}_{2}$ reduction, $\mathrm{Fe}(\mathrm{OH})_{3}$ reduction and $\mathrm{SO}_{4}^{2-}$ reduction) are modelled with four bacteria groups $\left(X_{1}, X_{2}\right.$, $X_{3}$, and $X_{4}$ ).

The general form of contaminant transport equation for the mobile components in the aqueous phase with the reaction term can be written as follow (Perera et al., 2009):

$$
\begin{aligned}
& \frac{\partial C_{m o b}}{\partial t}+\frac{u^{\prime} \partial C_{m o b}}{\partial x}+\frac{v^{\prime} \partial C_{m o b}}{\partial y}= \\
& \frac{\partial}{\partial x}\left(D_{x x} \frac{\partial C_{m o b}}{\partial x}+D_{x y} \frac{\partial C_{m o b}}{\partial y}\right)+ \\
& \frac{\partial}{\partial y}\left(D_{y y} \frac{\partial C_{m o b}}{\partial y}+D_{y x} \frac{\partial C_{m o b}}{\partial x}\right)+\sum_{i=1}^{3} S_{i}
\end{aligned}
$$

Where Cmob is the mobile phase species concentration. $u^{\prime}$ and $v^{\prime}$ are the components of real 


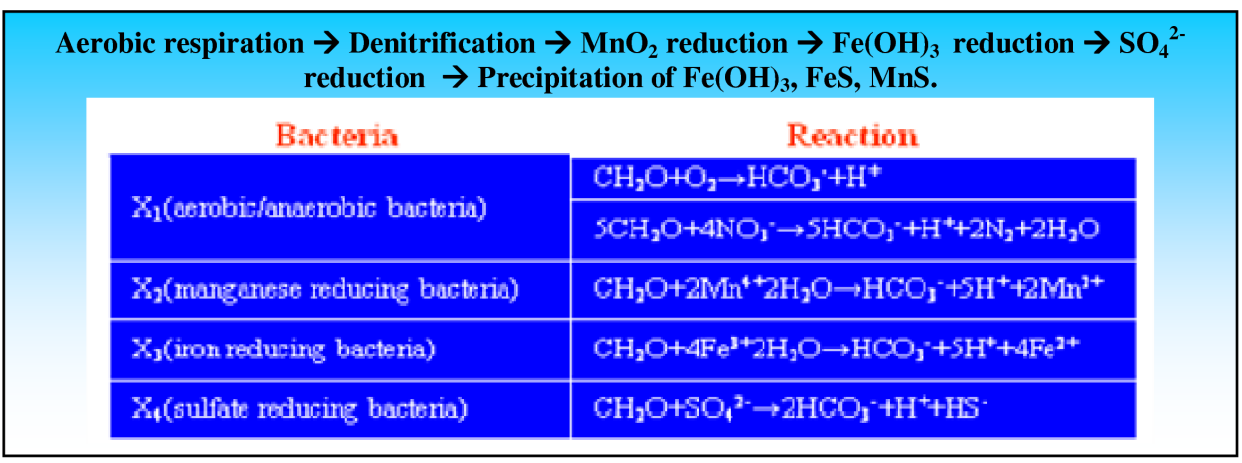

Figure 4: Sequence of major biological reactions considered in the biogeochemical model (Perera et al., 2009)

pore velocities in $x$ and $y$ directions. $S_{i}$ is the source/sink term which represents the solute exchange between different phases.

The dispersion coefficients, dependent on the real pore velocity, are represented as follows (in Perera et al., 2008):

$$
\begin{aligned}
& D_{x x}=\frac{\alpha_{L} u^{\prime 2}}{V}+\frac{\alpha_{T} v^{\prime 2}}{V}+\tau \cdot D_{M} \\
& D_{y y}=\frac{\alpha_{T} u^{\prime 2}}{V}+\frac{\alpha_{L} u^{\prime 2}}{V}+\tau \cdot D_{M} \\
& D_{x y}=D_{y x}=\frac{\left(\alpha_{L}-\alpha_{T}\right) u^{\prime} v^{\prime}}{V}
\end{aligned}
$$

Where $\alpha_{L}$ and $\alpha_{T}$ are the microscopic dispersion lengths related to the sand particle diameter, $v=\sqrt{\left(u^{\prime 2}+v^{\prime 2}\right)}$, and $D_{M}$ is the fluid molecular diffusion coefficient. $\tau$ is the tortuosity (Perera et al., 2008).

The source-sink term $\left(S_{i}\right)$ of Equation (3) describes the solute exchange between model phases. The solute exchange driving force is the difference between the concentrations of the species in different phases. The following equations describe the solute exchange between model phases (Perera et al., 2009).

The exchange of solute between the mobile phase and the bio phase $S_{1}$ is defined as:

$$
\begin{aligned}
S_{1} & =\frac{\alpha\left(1-\varepsilon_{0}\right)}{a} \cdot \frac{\theta_{b i o} \sqrt{D_{L}}}{\theta_{b i o}+\theta_{w}}\left(C_{b i o}-C_{m o b}\right) \\
& =\alpha^{\prime}\left(C_{b i o}-C_{m o b}\right) \\
\alpha^{\prime} & =\frac{\alpha\left(1-\varepsilon_{0}\right)}{a} \cdot \frac{\theta_{b i o} \sqrt{D_{L}}}{\theta_{b i o}+\theta_{w}}
\end{aligned}
$$

The exchange of solute between the mobile phase and the matrix phase $S_{2}$ is defined as:

$$
\begin{aligned}
S_{2} & =\frac{\beta\left(1-\varepsilon_{0}\right)}{a} \cdot \frac{\theta_{\text {mat }} \sqrt{D_{L}}}{\theta_{\text {mat }}+\theta_{w}}\left(C_{\text {mat }}-C_{\text {mob }}\right) \\
& =\beta^{\prime}\left(C_{\text {mat }}-C_{\text {mob }}\right) \\
\beta^{\prime} & =\frac{\beta\left(1-\varepsilon_{0}\right)}{a} \cdot \frac{\theta_{\text {bio }} \sqrt{D_{L}}}{\theta_{b i o}+\theta_{w}}
\end{aligned}
$$

The exchange of solute between the bio and matrix phases $S_{3}$ is defined as:

$$
\begin{aligned}
S_{3} & =\frac{\gamma\left(1-\varepsilon_{0}\right)}{a} \cdot \frac{\theta_{\text {mat }} \sqrt{D_{L}}}{\theta_{\text {bio }}+\theta_{\text {mat }}}\left(C_{\text {bio }}-C_{\text {mat }}\right) \\
& =\alpha^{\prime}\left(C_{\text {bio }}-C_{\text {mat }}\right) \\
\gamma^{\prime} & =\frac{\gamma\left(1-\varepsilon_{0}\right)}{a} \cdot \frac{\theta_{b i o} \sqrt{D_{L}}}{\theta_{\text {bio }}+\theta_{w}}
\end{aligned}
$$

Where $C_{m o b}, C_{b i o}$ and $C_{m a t}$ are the concentrations of solute in the mobile phase, bio phase and matrix phase respectively. $\alpha$ is the exchange coefficient between bio phase and mobile phase. $\beta$ is the exchange coefficient between matrix phase and mobile phase. $\gamma$ is the exchange coefficient between bio phase and matrix phase. $\alpha^{\prime}, \beta^{\prime}$ and $\gamma^{\prime}$ are the simplified exchange coefficients. $\varepsilon_{0}$ is the initial porosity, $a$ is the diameter of uniform soil particle and bio, mat and $\mathrm{w}$ are the specific volume of bio, matrix and mobile phases respectively. $D_{L}$ is the dispersion coefficient (Perera et al., 2009).

\section{Methods}

Finite different approximation is used to solve the problem. The finite difference approximations are derived from the fundamental definition of derivative and Taylor series expansion of a function $f(x)$. When a function $f(x)$ and 
its derivatives are single valued, finite, and continuous function of $x$, then by Taylor's series (in Jinno et al., 2001).

The method of characteristic is one of the solution technique used to solve the solute transport in porous media. It was originally applied by Garder et al. (1964) for calculation of miscible displacement in reservoir simulation

\section{Results and Discussions}

The some parameters to input the redox model were show in Keophousone et al. (2010a). Based on Keophousone et al. (2010b), the research of two-dimensional groundwater flow was simulated; therefore the flow modeling has been simulated again for satisfying with parameters data and site situation. Beside the flow simulation, the solute transport has been simulated either (in Keophousone et al., 2010c), and the calibration of parameter were edited afterward to make the model in reality.

The redox model was applied to the selected cross section under the following chemical species distribution which is shown in Table 1. Redox model was applied for two years of simulation and results are shown for bacteria growth, mobile phase species and matrix phase species along the borehole $\mathrm{BH} 1$ were chosen. Thus, the organic carbon supply from the matrix phase was kept constant and the velocity profile was followed as done for flow simulation (Keophousone et al., 2010). Moreover, constant supplies of $\mathrm{MnO}_{2}$ are also assigned. The organic carbon (1.0 mg/L; Perera et al., 2009) is continuously supplied from the top soil layer where cocist of sandy silt. Oxygen is infiltrated from the ground surface at the constant concentration of $8 \mathrm{mg} / \mathrm{L}$ with the infiltrated water (Perera et al., 2009).

On Table 1 shows the initial conditions assigned for redox model and the assigned boundary conditions for the simulation. The initial bacterial concentrations for aerobic and anaerobic bacteria were kept as $0.001 \mathrm{mg} / \mathrm{L}$. Redox model was applied for two years simulation and results are shown for bacteria growth, mobile phase species and matrix phase species along the borehole $\mathrm{BH} 1$.
As shown on Figure 6 to 8 , the obtained numerical results show the formation of two reduced zones. One reduced zone has been formed at depths between $0.0 \mathrm{~m}$ and $0.7 \mathrm{~m}$, and another one has been formed below $2.3 \mathrm{~m}$ depth, this result can be observed by matrix phase (Figure 7). The reason for the redox zone is obvious.

\section{Aerobic Oxidation, Denitrification and Growth of Bacteria $X_{1}$}

According to Figure 6, bacteria $X_{1}$ growth is dominant in the freshwater region (Figure 6) and no or less growth can be seen in the anaerobic source region of the aquifer. The gradual decrease of $\mathrm{CH}_{2} \mathrm{O}$ in the aerobic freshwater region is the main reason for the decrease of bacteria $X_{1}$ growth after 30 days.

Due to the consumption of $\mathrm{CH}_{2} \mathrm{O}$ in the freshwater region of bio phase by bacteria $\mathrm{X}_{1}, \mathrm{CH}_{2} \mathrm{O}$ in the freshwater region of the matrix phase is decreased and it is correctly simulated and shown in Figure 7. The growth of bacteria $X_{1}$ in the freshwater region is controlled by the available $\mathrm{CH}_{2} \mathrm{O}$. As a result of continuous infiltration of rainwater with the $8 \mathrm{mg} / \mathrm{L}$ of $\mathrm{O}_{2}$ concentration, there is enough $\mathrm{O}_{2}$ for bacteria $X_{1}$ to grow. However, there is no constant $\mathrm{CH}_{2} \mathrm{O}$ supply for the freshwater region. Therefore, when the available $\mathrm{CH}_{2} \mathrm{O}$ is consumed, the growth of bacteria $X_{1}$ hinders. Moreover, in Figure 8 . $\mathrm{NO}_{3}^{-}$concentration decreases gradually due to the denitrifying $\left(\mathrm{NO}_{3}^{-}\right.$reduce to bacteria $\left.X_{1}\right)$ process of bacteria $X_{1}$. The concentration variations of $\mathrm{O}_{2}$ and $\mathrm{NO}_{3}^{-}$with the metabolism of bacteria $X_{1}$ imply that the redox model can simulate the growth of aerobic and denitrify bacteria under the available $\mathrm{CH}_{2} \mathrm{O}$ appropriately.

\section{Reduction of $\mathrm{MnO}_{2}$ and growth of bacteria $\mathrm{X}_{2}$}

Formation of $\mathrm{Mn}^{2+}$ and $\mathrm{Fe}^{2+}$ could be observed as a result of the reduction of $\mathrm{MnO}_{2}$ and $\mathrm{Fe}(\mathrm{OH})_{3}$ below $2.3 \mathrm{~m}$. Bacteria $\mathrm{X}_{2}$ reduce $\mathrm{MnO}_{2}$ to $\mathrm{Mn}^{2+}$ under anaerobic conditions. Figure 7 shows the growth of $\mathrm{MnO}_{2}$ reducing bacteria $X_{2}$. The decrease of $\mathrm{MnO}_{2}$ in the matrix phase (Figure 7) corresponds well with the bacteria $\mathrm{X}_{2}$ growth which is shown in Figure 6. 
Table 1: Initial chemical species distribution for redox model

\begin{tabular}{l|c|c|c|c}
\hline \multirow{2}{*}{ Chemical Species } & \multicolumn{2}{|c|}{ Mobile phase (mg/L) } & \multirow{2}{\text{Biophase}}{} & $\begin{array}{c}\text { Matrix phase } \\
(\mathbf{m g} / \mathbf{L})\end{array}$ \\
\cline { 2 - 3 } & Fresh water & Source water & $(\mathbf{m})$ & - \\
\hline $\mathrm{O}_{2}$ & 0.0 & 3.4 & 0.0 & - \\
\hline $\mathrm{NO}_{3}^{-}$ & 0.05 & 0.002 & 0.0 & 5.0 \\
\hline $\mathrm{MnO}_{2}$ & - & - & 0.0 & 1.5 \\
\hline $\mathrm{Fe}(\mathrm{OH})_{3}$ & - & - & 0.0 & - \\
\hline $\mathrm{Fe}^{2+}$ & 0.0 & 0.0 & 0.0 & - \\
\hline $\mathrm{Mn}^{2+}$ & 0.0 & 0.0 & 0.0 & 0.5 \\
\hline $\mathrm{CH}_{2} \mathrm{O}$ & 0.6 & 0.5 & 0.0 & - \\
\hline $\mathrm{SO}_{4}{ }^{2-}$ & 12.0 & 500 & - & \\
\hline
\end{tabular}

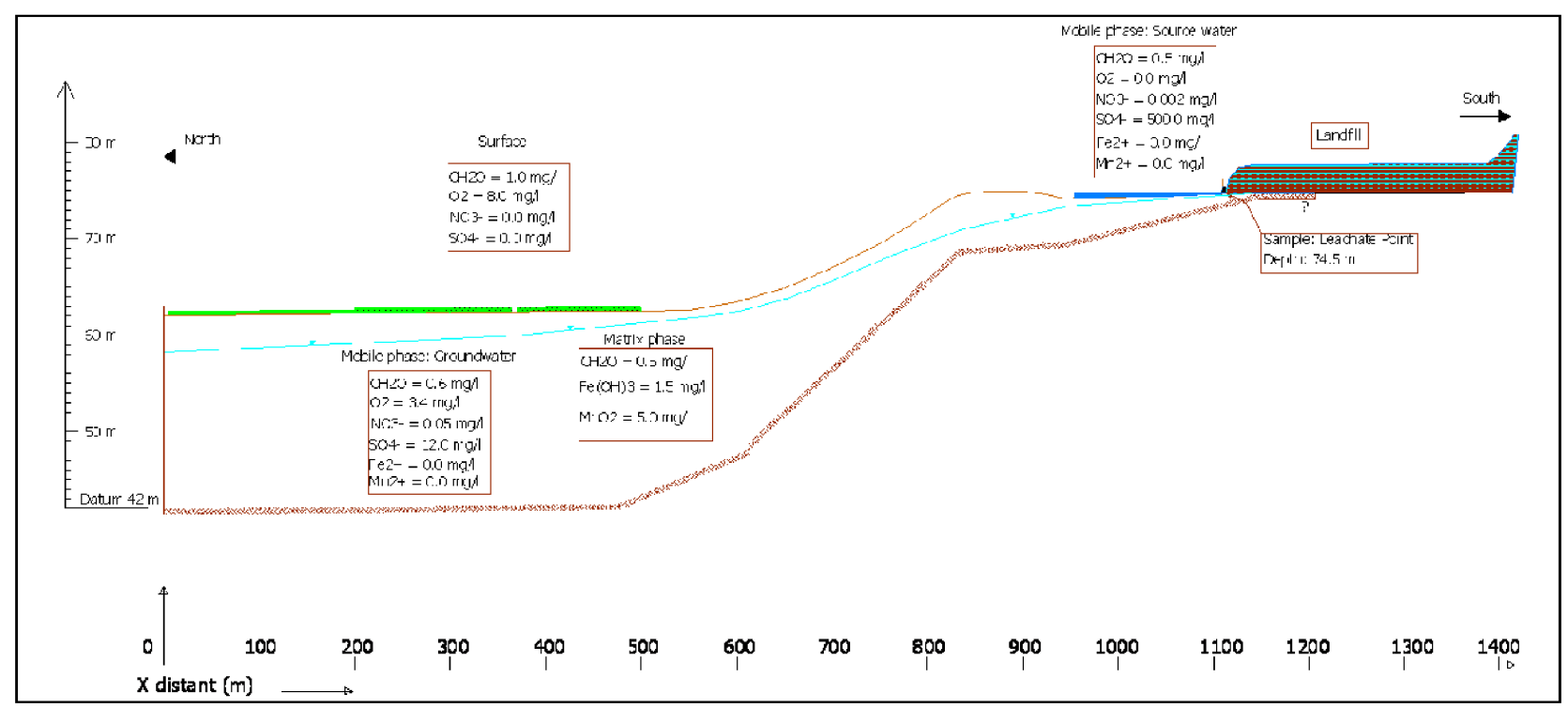

Figure 5: Initial and boundaries of chemical species distribution for redox model 

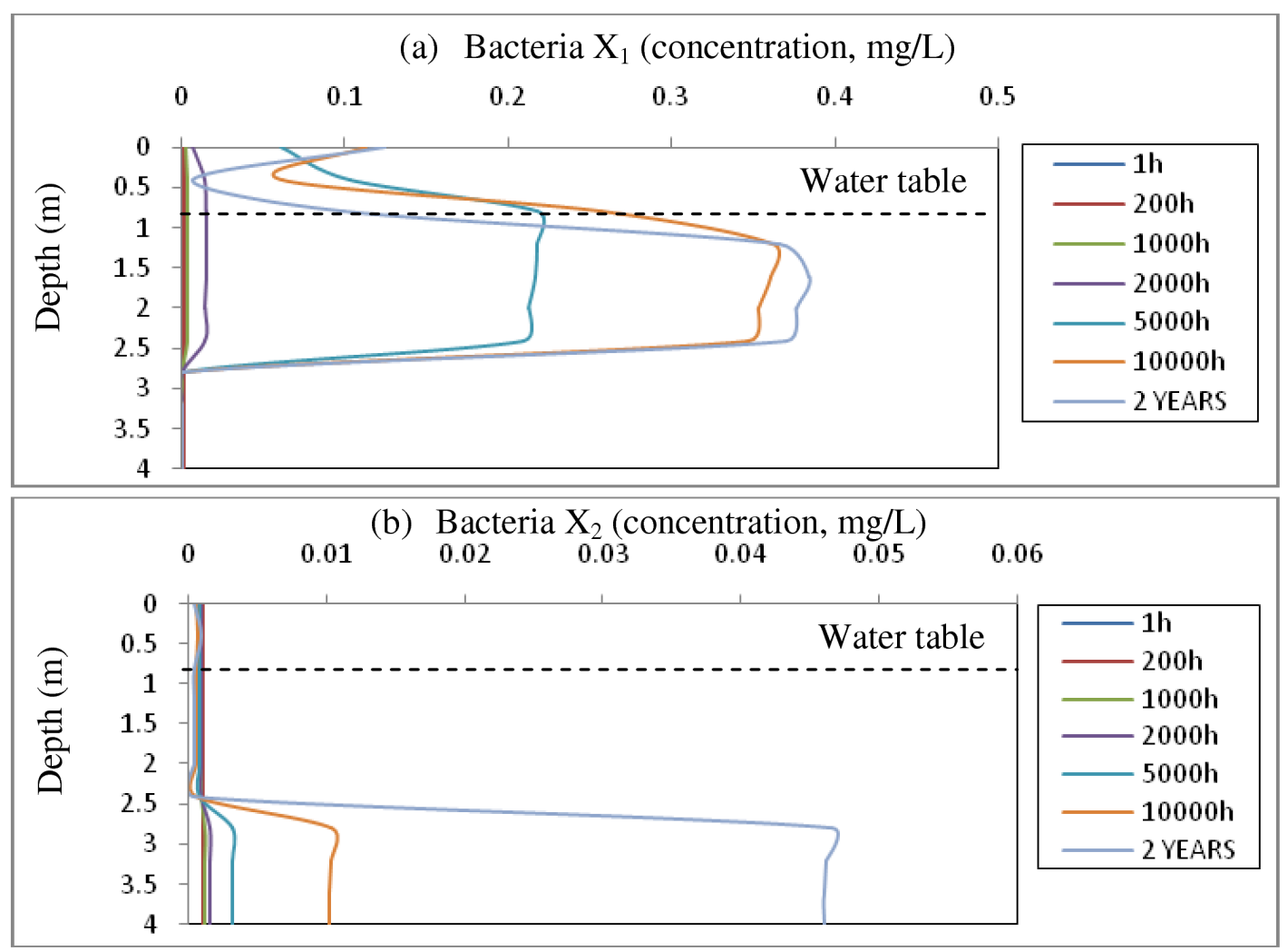

(c) Bacteria $\mathrm{X}_{3}$ (concentration, $\mathrm{mg} / \mathrm{L}$ )

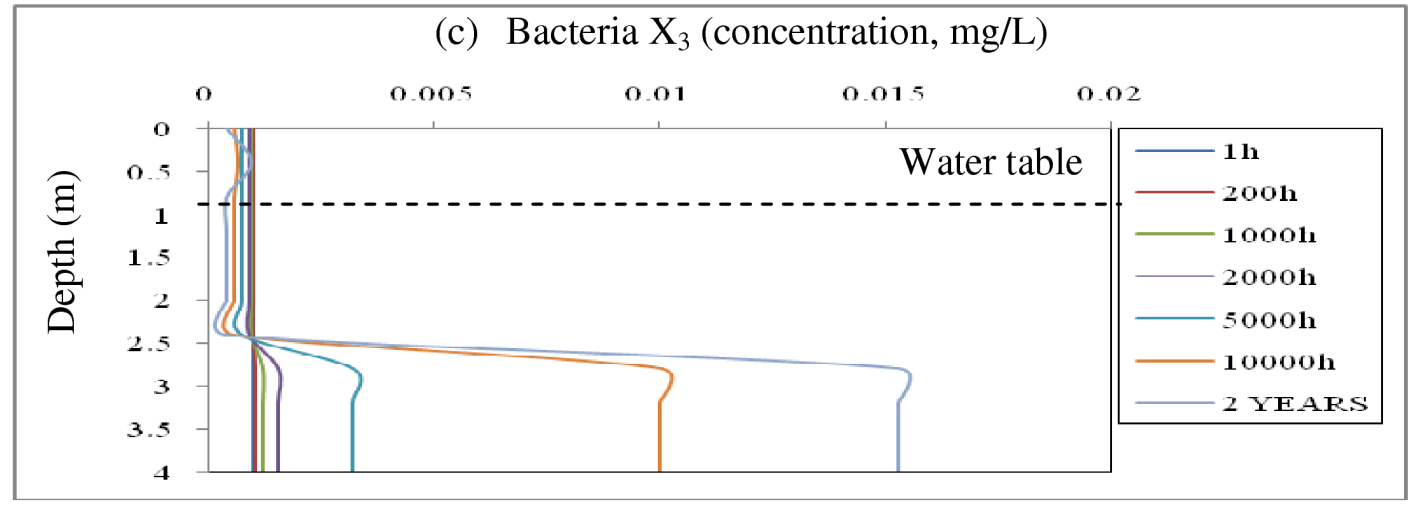

Figure 6: Numerical results for aerobic and anaerobic bacterial growth (at BH1) 

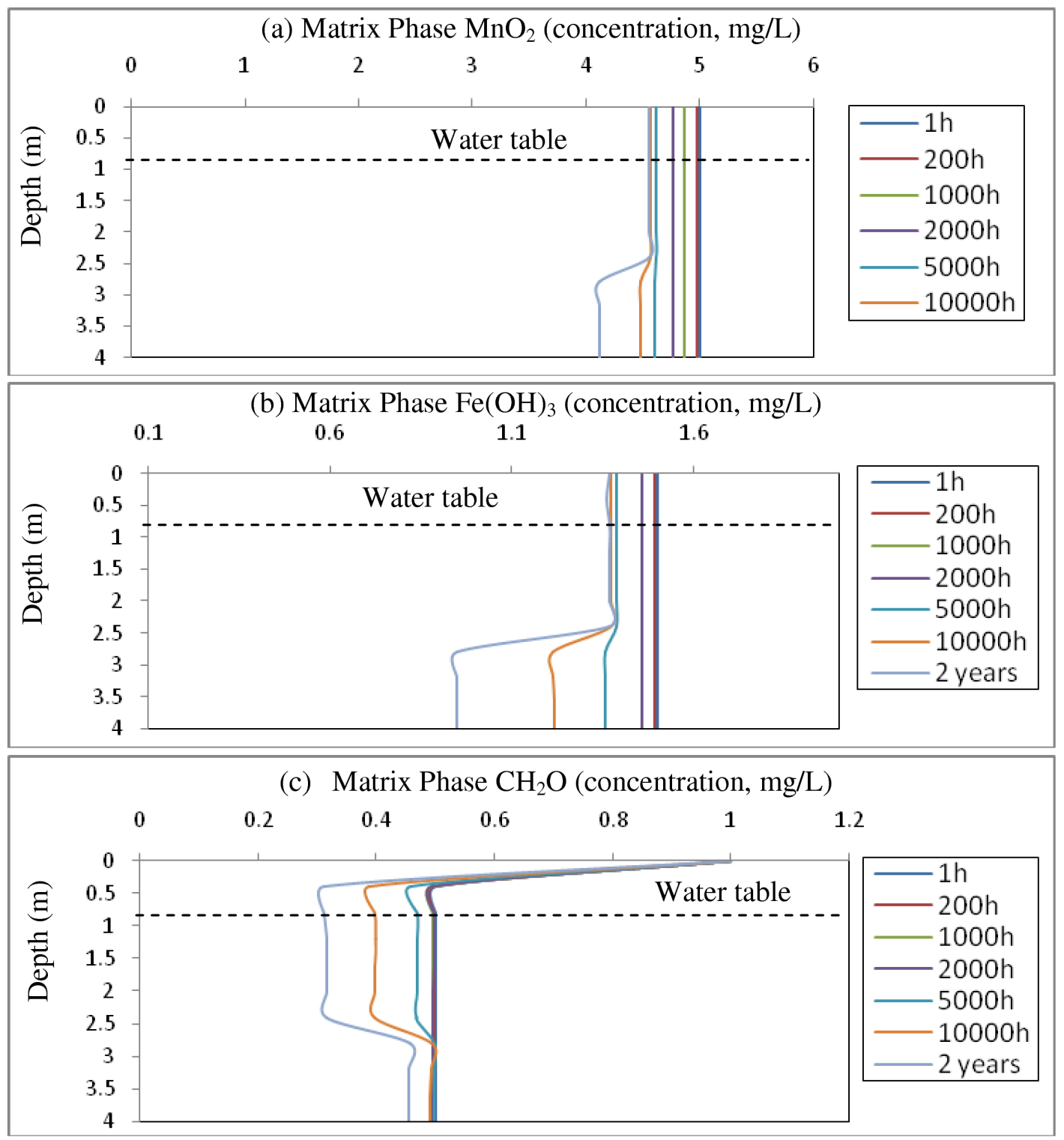

Figure 7: Numerical results for concentration variations of the matrix phase species (at BH1) 

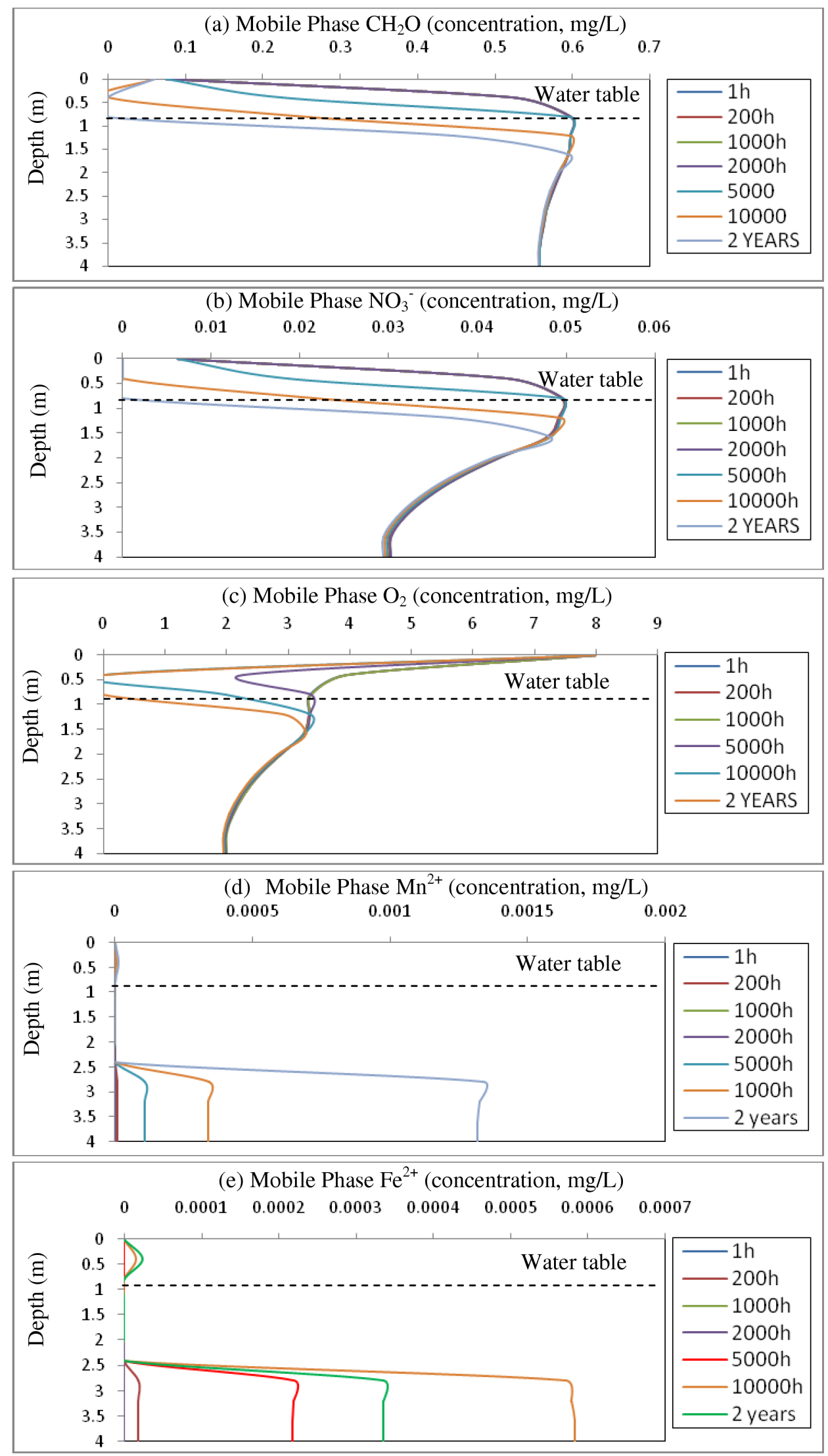

Figure 8: Numerical results for concentration variations of the mobile phase species (at $\mathrm{BH} 1$ ) 
Figure 8 shows the concentration of formed $\mathrm{Mn}^{2+}$ in mobile phase. Bacteria $\mathrm{X}_{2}$ growth is significant in the anaerobic source region of the aquifer. Constant $\mathrm{CH}_{2} \mathrm{O}$ layer provides abundant electron donor environment which is favorable for bacterial growth. According to Figure 6 growth of bacteria $X_{2}$ increases up to 2 years. The reason for that is the availability of $\mathrm{MnO}_{2}$. Bacteria $\mathrm{X}_{2}$ use available $\mathrm{MnO}_{2}$ in the organic carbon region. Availability of $\mathrm{CH}_{2} \mathrm{O}$ and $\mathrm{MnO}_{2}$ under anaerobic condition is favorable for the growth of bacteria $X_{2}$. Availability of $\mathrm{CH}_{2} \mathrm{O}$ and $\mathrm{MnO}_{2}$ in the anaerobic region are the determining factors for bacteria $\mathrm{X}_{2}$. Redox model is able to simulate the growth of bacteria $X_{2}$ appropriately under the assigned conditions.

\section{Reduction of $\mathrm{Fe}(\mathrm{OH})_{3}$, the growth of bacteria $\mathrm{X}_{3}$ and precipitation of $\mathrm{Fe}(\mathrm{OH})_{3}$}

The reduction of $\mathrm{Fe}(\mathrm{OH})_{3}$ occurs in the anaerobic region due to the metabolism of bacteria $X_{3}$ in the redox model. On Figure 8 shows the formation of $\mathrm{Fe}^{2+}$ in mobile phase due to the reduction of $\mathrm{Fe}(\mathrm{OH})_{3}$ in the bio phase. Figure 6 shows the bacteria $X_{3}$ growth for ten years while in Figure 7 shows the concentration changes of $\mathrm{Fe}(\mathrm{OH})_{3}$ in the matrix phase.

The decrease of the growth of bacteria $X_{3}$ in the constant $\mathrm{CH}_{2} \mathrm{O}$ layer is due to the consumption of $\mathrm{Fe}(\mathrm{OH})_{3}$ in the bottom of the aquifer. Therefore, bacteria $X_{3}$ grows in that region until all the $\mathrm{Fe}(\mathrm{OH})_{3}$ is reduced by bacteria $X_{3}$. The precipitation of formed $\mathrm{Fe}^{2+}$ takes place in the mixing zone area, where $\mathrm{O}_{2}$ is available. The reduction of $\mathrm{Fe}(\mathrm{OH})_{3}$ takes place in the lower part of mixing zone and anaerobic source region of the aquifer at different rates according to the availability of $\mathrm{CH}_{2} \mathrm{O}$ and $\mathrm{Fe}(\mathrm{OH})_{3}$. High concentration of dissolved $\mathrm{Fe}^{2+}$ is a common water quality problem associated with groundwater. Therefore, the reduction of $\mathrm{Fe}(\mathrm{OH})_{3}$ is an important process to be considered in numerical simulations to enhance the understanding of biological involvement in groundwater.

The formed $\mathrm{Fe}^{2+}$ moves to the mixing zone with the advective flow and meets $\mathrm{O}_{2}$ and precipitates as $\mathrm{Fe}(\mathrm{OH})_{3}$. The precipitation of $\mathrm{Fe}(\mathrm{OH})_{3}$ is highlighted as the increase of
$\mathrm{Fe}(\mathrm{OH})_{3}$ concentration in the matrix zone. In Figure 7, the gradual increase of $\mathrm{Fe}(\mathrm{OH})_{3}$ concentration in the mixing zone region (elevation between $2.1 \mathrm{~m}$ to $2.3 \mathrm{~m}$ ) depicts the precipitation of $\mathrm{Fe}(\mathrm{OH})_{3}$. The $\mathrm{Fe}^{2+}$ concentration increases around the $2.3 \mathrm{~m}$ elevation in the mobile phase (Figure 8) is due the reduction of precipitated $\mathrm{Fe}(\mathrm{OH})_{3}$ in bottom edge of the mixing zone.

\section{Conclusions}

The calculation result shows that biochemical processes are important and must be taken to be considered in groundwater quality problem. The simulation results show the trends of groundwater quality alteration such as denitrification, $\mathrm{MnO}_{2}$ reduction and $\mathrm{Fe}(\mathrm{OH})_{3}$ reduction. Therefore, due to the limitations in the field measurements and difficulties in the biogeochemical parameter identification, it was impossible to simulate the exact situation which is prevailing in the Piyungan landfill area. Further efforts are needed to modify the redox model parameters in the case where more accurate groundwater chemistry is needed.

\section{Acknowledgements}

This study has been supported financially by AUN/SEED-Net, JICA. The authors would like to acknowledge and express their sincere thanks and appreciations to Prof. Kenji Jinno. Our gratitude is further expressed to Regency of Bantul, Yogyakarta Special Province for their kind supporting and kind helps during data collection.

\section{References}

Garder, A.O., Peaceman, D.W. Jr., Pozzi, A.L. (1964). Numerical calculation of multi dimensional missible displacement by the method of characteristics. Society of Petroleum Engineers Journal, Vol (6), pp. 175-182.

Jinno, K., Momii, K., Fujino, K., Nakagawa, K., Hosokawa, T., Egusa, N. and Hiroshiro, Y. 2001. Numerical analysis of mass transport in the groundwater. ISBN 4-87378-689-4. Kyushuuniversity publication, Japan. 
Keophousone, P., Karnawati., D. Hendrayana. H., Putra, D.P.E., and Jinno, K. (2010a), Hydrogeological factor controls on groundwater contaminant movement from landfill leachate, Case Study: Piyungan Landfill, Yogyakarta, Central Java, Indonesia, International Symposium and The 2nd AUN/SEED-Net Regional Conference on GeoDisaster Mitigation in ASEAN, Indonesia, pp. 431-438.

Keophousone, P., Karnawati., D. Hendrayana. H., Putra, D.P.E., and Jinno, K. (2010b), 2-D vertical groundwater flow simulation by using numerical method, Case Study: Piyungan Landfill, Yogyakarta, Indonesia, International Symposium on a Robust and Resilient Society against Natural Hazards \& Environmental Disasters and the Third AUN/SEED-Net Regional Conference on Geo-Disaster Mitigation, Japan, pp. 325-334.

Keophousone, P., Karnawati., D. Hendrayana. H., Putra, D.P.E., and Jinno, K. (2010c), Tracing of solute transport at Piyungan Landfill Site, Yogyakarta, Central Java, Indonesia, International Symposium on a Robust and Resilient Society against Natural Hazards \& Environmental Disasters and the 3rd AUN/SEED-Net Regional Con- ference on Geological Engineering Research in ASEAN, Cambodia, pp 172-178.

Putra, D.P.E., Hendrayana, H., and Sukandarrumidi. (2001), Groundwater Contamination Modeling, Case Study: Piyungan Landfill Area, D.I.Yogyakarta, 30th Annual Conference 10th Regional Congress, Yogyakarta, Indonesia.

Putra, D.P.E. (2001), Leachate Contamination on Groundwater at The Landfill and Surrounding Area, Subresidency, Bantul Residency, Yogyakarta. Master thesis, Geological Engineering Department, Gadjah Mada University. Unpublished.

Perera, E.D.P., Jinno, K., Tsutsumi, A., and Hiroshiro, Y. (2008), Development and Verification of a Three Dimensional Density Dependent Solute Transport Model for Seawater Intrusion, Memoirs of the Faculty of Engineering, Kyushu University, Vol. 68, No.2, pp. 94-106.

Perera, E.D.P., Jinno, K., and Hosokawa, T. (2009), Simulation of Bio-geochemical processes in a coastal aquifer, Annual Journal of Hydraulic Engineering, JSCE, Vol. 53. 